Article

\title{
Euphosantianane A-D: Antiproliferative Premyrsinane Diterpenoids from the Endemic Egyptian Plant Euphorbia Sanctae-Catharinae
}

\author{
Mohamed-Elamir F. Hegazy ${ }^{1,2} \mathbb{E}^{(0)}$, Ahmed R. Hamed ${ }^{1,3}$, Mahmoud A. A. Ibrahim ${ }^{4}$ (D), \\ Zienab Talat ${ }^{5}$, Eman H. Reda ${ }^{5}$, Nahla S. Abdel-Azim ${ }^{1}$ (D), Faiza M. Hammouda ${ }^{1}$, \\ Seikou Nakamura ${ }^{6}$, Hisashi Matsuda ${ }^{6}$ (D), Eman G. Haggag ${ }^{7}$, Paul W. Paré ${ }^{8, *(D)}$ and \\ Thomas Efferth ${ }^{2}$ \\ 1 Chemistry of Medicinal Plants Department, National Research Centre, 33 El-Bohouth St., Dokki, Giza 12622, \\ Egypt; Elamir77@live.com (M.-E.F.H.);n1ragab2004@yahoo.com (A.R.H.); \\ nahlaabdelazim@yahoo.com (N.S.A.-A.); fmhammouda@yahoo.com (F.M.H.) \\ 2 Department of Pharmaceutical Biology, Institute of Pharmacy and Biochemistry, University of Mainz, \\ Staudinger Weg 5, 55128 Mainz, Germany; efferth@uni-mainz.de \\ 3 Biology Unit, Central Laboratory for Pharmaceutical and Drug Industries Research Division, \\ National Research Centre, 33 El-Bohouth St., Dokki, Giza 12622, Egypt \\ 4 Computational Chemistry Laboratory, Chemistry Department, Faculty of Science, Minia University, \\ Minia 61519, Egypt; m.ibrahim@compchem.net \\ 5 Phytochemistry Lab., National Organization for Drug Control and Research, Giza 12622, Egypt; \\ zizishakour@yahoo.com (Z.T.); dremanhusseinreda@gmail.com (E.H.R.) \\ 6 Department of Pharmacognosy, Kyoto Pharmaceutical University, Misasagi, Yamashina-ku, Kyoto 607-8412, \\ Japan; naka@mb.kyoto-phu.ac.jp (S.N.); matsuda@mb.kyoto-phu.ac.jp (H.M.) \\ 7 Department of Pharmacognosy, Helwan University, Cairo 12622, Egypt; wemisr@hotmail.com \\ 8 Department of Chemistry and Biochemistry, Texas Tech University, Lubbock, TX 79409, USA \\ * Correspondence: paul.pare@ttu.edu; Tel.: +1-806-834-0461; Fax: +1-806-742-1289
}

Received: 28 July 2018; Accepted: 15 August 2018; Published: 1 September 2018

\begin{abstract}
Euphorbia species are rich in diterpenes. A solvent extraction of Euphorbia sanctae-catharinae, a species indigenous to the Southern Sinai of Egypt, afforded several premyrsinane diterpenoids (1-4) as well as previously reported metabolites (5-13) that included three flavonoids. Isolated compounds were chemically characterized by spectroscopic analysis. Identified compounds were bioassayed for anti-proliferative activity in vitro against colon (Caco-2) and lung (A549) tumor cell lines. Compound 9 exhibited robust anti-proliferative activity against $\mathrm{A} 549$ cells $\left(\mathrm{IC}_{50}=3.3 \mu \mathrm{M}\right)$. Absolute configurations for 8 versus 9 were determined by experimental and TDDFT-calculated electronic circular dichorism (ECD) spectra.
\end{abstract}

Keywords: Euphorbia sanctae-catharinae; Euphorbiaceae; diterpenes; flavonoids; TDDTF-ECD; tumor anti-proliferative activity

\section{Introduction}

The genus Euphorbia is the largest genus in the family Euphorbiaceae. The genus comprises over 2000 species worldwide [1] and its global distribution includes more than 750 species in Africa and 42 indigenous to Egypt [2]. All plants in the genus share a poisonous, milky-white, latex-like sap as well as a unique floral structure, in which each flower in the cluster is reduced to its barest of essential parts for sexual reproduction. Euphorbia species have been widely used in folk medicine for the treatment of diarrhea, inflammation, and swellings and the milky sap has been tested as a wart 
remover [3-5]. Some species have been used in the treatment of dermatosis, paralysis and body pain as well as a poultice for skin ulcerations [6]. A number of biological activities ranging from cytotoxic [7], hepatoprotective [8,9], antispasmodic [10], anti-inflammatory [11], antibacterial [12,13], antifungal [10] and anti-mutagenic [14], antiviral [15] have been reported.

Some Euphorbia species are indigenous to the Sinai Peninsula $[16,17]$ with E. sanctae-catharinae (also known as St. Katherine spurge) endemic to the Gebel Wadi, a system of deep/dry river valleys separated by the high elevation Katherine Mountains. As part of our research to investigate and biologically evaluate the wild Egyptian plants [18-25], herein, it is the first phytochemical investigation of E. sanctae-catharinae that specifically targets secondary metabolites that may exhibit anti-tumor activity.

\section{Results and Discussion}

A methylene chloride/methanol (1:1) extract of air-dried, aerial parts of E. sanctae-catharinae was separated into pure chemical components using normal and reversed phase chromatographic separations to afford new (1-4) as well as previously isolated (5-13) compounds (Figure 1).

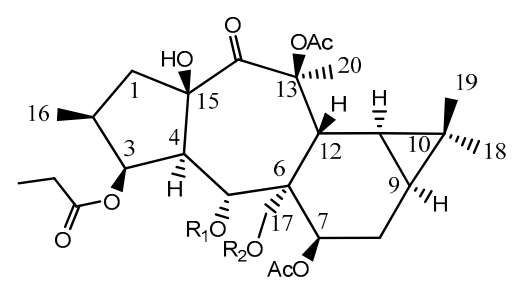

$$
\begin{array}{lll}
\mathbf{1} & \mathrm{R}_{1}=3 \mathrm{MeBu} & \mathrm{R}_{2}=\mathrm{Ac} \\
\mathbf{2} \mathrm{R}_{1}=\mathrm{iBu} & \mathrm{R}_{2}=\mathrm{Bz} \\
\mathbf{3} \mathrm{R}_{1}=\mathrm{Bz} & \mathrm{R}_{2}=\mathrm{Bz} \\
\mathbf{4} \mathrm{R}_{1}=2 \mathrm{MeBu} & \mathrm{R}_{2}=\mathrm{Nic} \\
\mathbf{5} \mathrm{R}_{1}=2 \mathrm{MeBu} & \mathrm{R}_{2}=\mathrm{Ac} \\
\mathbf{6} \mathrm{R}_{1}=\mathrm{iBu} & \mathrm{R}_{2}=\mathrm{Ac} \\
\mathbf{7} & \mathrm{R}_{1}=\mathrm{iBu} & \mathrm{R}_{2}=\mathrm{Nic}
\end{array}
$$

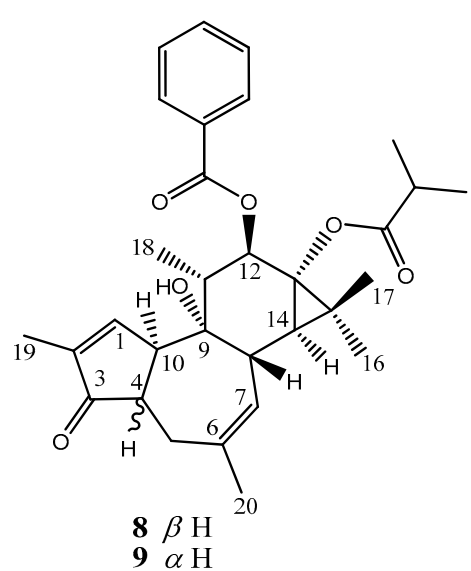<smiles>[R8]c1cc(C2Oc3cc(O)cc(O)c3C(=O)C2O[C@@H]2O[C@H](C)[C@@H](O)[C@H](O)[C@H]2O)cc([R])c1[2H]</smiles>

$10 \mathrm{R}_{1}=\mathrm{OH}, \mathrm{R}_{2}=\mathrm{OH}, \mathrm{R}_{3}=\mathrm{H}$

$11 \mathrm{R}_{1}=\mathrm{H}, \mathrm{R}_{2}=\mathrm{OH}, \mathrm{R}_{3}=\mathrm{H}$

$12 \mathrm{R}_{1}=\mathrm{OH}, \mathrm{R}_{2}=\mathrm{OH}, \mathrm{R}_{3}=\mathrm{OH}$<smiles>O=C1c2c(O)cc(O)cc2OC(c2cc(O)c(O)c(O)c2)C1O[C@@H]1O[C@H](CO)[C@@H](O)[C@H](O)[C@H]1O</smiles>

13

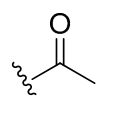<smiles>CCC(C)C(C)=O</smiles><smiles>CCCC(C)C(C)C</smiles><smiles>CCC(C)C(C)CCC(=O)c1ccccc1</smiles><smiles>CCC(=O)c1cccnc1</smiles>

Ac

$2 \mathrm{MeBu}$

3MeBu

iBu

$\mathrm{Bz}$

$\mathrm{Nic}$

Figure 1. Identified compounds from Euphorbia sanctae-catharinae. Ac = acetyl, $\mathrm{Bz}=$ benzoyl, $\mathrm{Nic}=$ nicotinoyl, $\mathrm{Bu}=$ butanoyl, $\mathrm{iBu}=$ isobutanoyl, $2 \mathrm{MeBu}=2$-methylbutanoyl, $2 \mathrm{MeBu}$ 3-dimethylbutanoyl, Nic = nicotinoyl. 
Compound 1 was obtained as colorless oil with positive optical rotation $\left([\alpha]_{\mathrm{D}}^{25}+20.0\right.$ in $\left.\mathrm{MeOH}\right)$. HRFABMS analysis showed a molecular ion peak at $m / z 673.3203[\mathrm{M}+\mathrm{Na}]^{+}$corresponding to a molecular formula of $\mathrm{C}_{34} \mathrm{H}_{50} \mathrm{O}_{12} \mathrm{Na}$ (calcd. 673.3200). The IR spectrum displayed absorption bands for $\mathrm{OH}\left(3532 \mathrm{~cm}^{-1}\right)$ and ester carbonyl $\left(1741 \mathrm{~cm}^{-1}\right)$ groups. The ${ }^{1} \mathrm{H}-\mathrm{NMR}$ spectrum contained signals typical for three acetyl groups at $\delta_{\mathrm{H}} 2.06,2.08$ and 2.09. The spectrum also displayed signals for seven methyl groups (one primary at $\delta_{\mathrm{H}} 1.08(6 \mathrm{H})$, three secondary at $\delta_{\mathrm{H}} 0.87,0.90$ and 0.92 , four tertiary at $\delta_{\mathrm{H}} 0.87,1.04$ and 1.68) and three oxygenated methine protons referred to ester functions at $\delta_{\mathrm{H}} 4.48$ $(\mathrm{d}, J=6.6), 5.24(\mathrm{dd}, J=3.6,6.0), 6.18(\mathrm{~d}, J=11.4)$ and one oxygenated methyelene at $\delta_{\mathrm{H}} 4.39(\mathrm{~d}, J=12.0)$ and $4.31(\mathrm{~d}, J=12.0)$. Additionally, two aliphatic methine $\delta_{\mathrm{H}} 0.72(\mathrm{~m})$ indicated the presence of a cyclopropane moiety (Table 1). ${ }^{13} \mathrm{C}-\mathrm{NMR}$ and DEPT spectra displayed 32 carbons including five ester carbonyls $\left(\delta_{C} 170.0,170.4,170.7,174.2\right.$ and 174.3), one free keto carbon $\left(\delta_{C} 204.5\right), 7$ methyls, 5 methylenes (one of them oxygenated), 8 methines (two of them oxygenated), and four quaternary carbons (two of them oxygenated). Ten degrees of unsaturation were deduced suggesting a tetracyclic diterpene premyrsinane skeleton. Two-dimensional NMR (COSY, HMQC and HMBC) comparisons with 7 that had been previously published suggested a 5/7/6 cyclic structure $[16,26,27]$. Differences in the spectroscopic data between 1 and $\mathbf{6}$ were limited to C-5. Indeed, functionality differences for Euphorbia premyrsinane diterpenoids are usually localized to C-3, C-5, C-7 and/or C-17. HRFABMS of 1 indicated the addition of a methlyene unit in comparison with 6. DEPT analysis confirmed an additional methylene group at $\delta_{\mathrm{C}} 42.8\left(\delta_{\mathrm{H}} 2.32, \mathrm{~m}\right)$ and correlations with signals at $\delta_{\mathrm{H}} 1.97(\mathrm{~m})$ and $\delta_{\mathrm{C}} 174.2$ in DQF-COSY and HMBC analyses, respectively, situated the methyl as an addition to the butyrate unit [28]. Moreover, an HMBC correlation between $\mathrm{H}-5\left(\delta_{\mathrm{H}} 6.18, \mathrm{~d}, J=11.4\right)$ and $\delta_{\mathrm{C}} 174.2$ established the presence of 2-methylbutyrate at $C-5\left(\delta_{C} 68.8\right)$. These data suggested that signals for a 2-methylbutyryl unit in 5 was replaced by 3-methylbutyryl moiety $\left(\delta_{C} 174.2,21.4,21.4,26.5,42.8\right)$ in 1 (Figure 2). This small modification was confirmed by COSY, HMBC analysis.

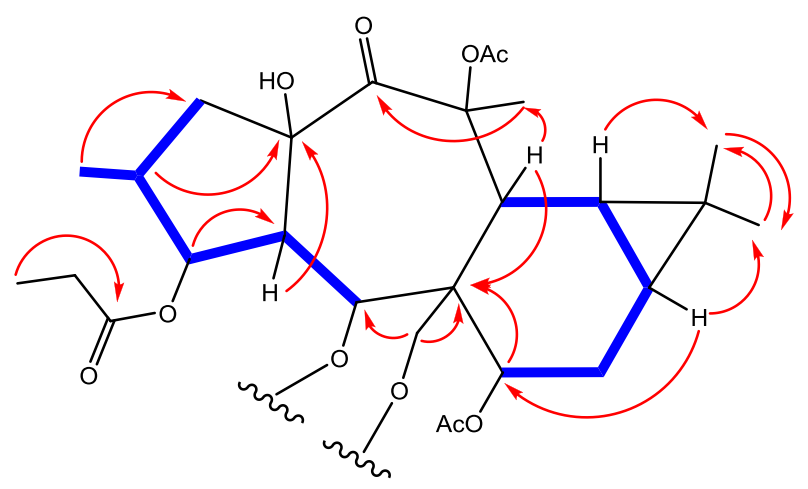

Figure 2. Observed DQF-COSY and HMBC correlations for 1-4.

The relative configuration was elucidated as based on biosynthetic presidency. For all naturally derived myrsinol diterpenes isolated to date, the three $(5 / 7 / 6)$ fused ring system that forms the myrsinol skeleton are joined in a trans configuration with $\mathrm{H}-4$ and $\mathrm{H}_{2}-17 \alpha$-oriented. Based on this initial configuration, NOE correlations between $\mathrm{H}-4$ and $\mathrm{H}-1$ provided evidence for an $\alpha$-assignment $\mathrm{H}-1$. NOE correlations between $\mathrm{H}-1 \alpha / \mathrm{H}-2$ and $\mathrm{H}-1 \beta / \mathrm{CH}_{3}-16$ established an $\alpha$-orientation for $\mathrm{H}-2$. NOE interactions between $\mathrm{H}-5 / 7-\mathrm{OAc}, \mathrm{H}-5 / \mathrm{H}-12$ and $\mathrm{H}-7 / \mathrm{H}_{2}-17$ established an $\alpha$-orientation for $\mathrm{H}-7$ and a $\beta$-orientation for H-12. NOESY correlations observed between $\mathrm{H}-1 \beta, \mathrm{H}-14$ and $\mathrm{H}-16$ indicated the positioning of these functional groups on the same ringside consistent with a cis configuration (Figure 3). All stereochemical assignments are consistent with previously reported premyrsinane diterpenes $[16,26]$. Therefore, the structure was assigned as premyrsinol-3-propanoate- $5(\alpha-3$ methyl) butyrate-7, 13, 17-triacetate (euphosantianane A). 
Table 1. ${ }^{1} \mathrm{H}-\mathrm{NMR}$ and ${ }^{13} \mathrm{C}-\mathrm{NMR}$ spectral data of compounds 1-5 (600 MHz, $\delta$-ppm).

\begin{tabular}{|c|c|c|c|c|c|c|c|c|}
\hline No. & 1 & & 2 & & 3 & & 4 & \\
\hline & $d_{\mathrm{H}}(J$ in $\mathrm{Hz})$ & $\delta_{C}$ & $d_{\mathrm{H}}(J$ in $\mathrm{Hz})$ & $\delta_{C}$ & $d_{\mathrm{H}}(J$ in $\mathrm{Hz})$ & $\delta_{\mathrm{C}}$ & $d_{\mathrm{H}}(J$ in $\mathrm{Hz})$ & $\delta_{C}$ \\
\hline $1 \alpha$ & $3.12 \mathrm{dd}(8.4,13.8)$ & 42.9 & $3.14 \mathrm{dd}(8.4,13.8)$ & 42.9 & $3.15 \mathrm{dd}(7.2,13.8)$ & 42.9 & $3.14 \mathrm{dd}(7.8,13.2)$ & 42.9 \\
\hline $1 \beta$ & $1.59 \mathrm{dd}(12.6,13.2)$ & & $1.60 \mathrm{dd}(13.2)$ & & $1.61 \mathrm{dd}(13.8,13.2)$ & & $1.61 \mathrm{dd}$ & \\
\hline 2 & $1.80 \mathrm{~m}$ & 37.5 & $1.86 \mathrm{~m}$ & 37.5 & $1.87 \mathrm{~m}$ & 37.3 & $1.79 \mathrm{~m}$ & 37.5 \\
\hline 3 & $5.24 \mathrm{dd}(3.6,6.0)$ & 78.4 & $5.23 \mathrm{t}$ & 78.4 & $5.36 \mathrm{t}(3.6)$ & 78.3 & $5.21 \mathrm{t}$ & 77.3 \\
\hline 4 & $2.32 \mathrm{~m}$ & 50.4 & $2.32 \mathrm{~m}$ & 50.5 & $2.34 \mathrm{~m}$ & 50.4 & $2.36 \mathrm{dd}(3.0)$ & 50.6 \\
\hline 5 & $6.18 \mathrm{~d}(11.4)$ & 68.8 & $6.21 \mathrm{~d}(12.0)$ & 69.1 & $6.46 \mathrm{~d}(11.4)$ & 69.9 & $6.23 \mathrm{~d}(12.0)$ & 69 \\
\hline 6 & - & 47.4 & - & 47.8 & 一 & 48.2 & - & 47.7 \\
\hline 7 & $4.48 \mathrm{~d}(6.6)$ & 70.7 & $4.72 \mathrm{~d}(6.6)$ & 71 & $4.97 \mathrm{~d}(6.6)$ & 70.7 & $4.85 \mathrm{~d}(12.6)$ & 70.8 \\
\hline $8 \alpha$ & $2.09 \mathrm{~m}$ & 23.9 & $2.14 \mathrm{~m}$ & 21.4 & $2.05 \mathrm{~m}$ & 22.2 & $2.09 \mathrm{~m}$ & 23.9 \\
\hline $8 \beta$ & 1.80 brd (17.0) & 23.9 & 1.77 brd (17.0) & 21.4 & 1.87 brd (17.0) & 22.2 & $1.90 \mathrm{~d}(13.2)$ & 23.9 \\
\hline 9 & $0.72 \mathrm{~m}$ & 18.9 & $0.77 \mathrm{~m}$ & 18.4 & $0.72 \mathrm{~m}$ & 19.1 & $0.62 \mathrm{~m}$ & 19 \\
\hline 10 & - & 18.2 & - & 18.3 & - & 18.4 & - & 18.3 \\
\hline 11 & $0.72 \mathrm{~m}$ & 21.4 & $0.77 \mathrm{~m}$ & 18.5 & $0.72 \mathrm{~m}$ & 21.5 & $0.62 \mathrm{~m}$ & 21.3 \\
\hline 12 & $3.37 \mathrm{~d}(6)$ & 34.8 & $3.46 \mathrm{~d}(5.4)$ & 33.9 & $3.55 \mathrm{~d}(6.6)$ & 35.3 & $3.46 \mathrm{~d}(3.6)$ & 35 \\
\hline 13 & - & 86.0 & - & 85.9 & 一 & 85.9 & 一 & 85.8 \\
\hline 14 & 一 & 204.5 & - & 204.5 & - & 204.4 & 一 & 204.3 \\
\hline $15-\mathrm{OH}$ & $4.44 \mathrm{~s}$ & 84.1 & $4.44 \mathrm{~s}$ & 84.1 & $4.45 \mathrm{~s}$ & 84.2 & $4.48 \mathrm{~s}$ & 84.1 \\
\hline 16 & $0.87 \mathrm{~d}(6.0)$ & 14.1 & $0.86 \mathrm{~d}(1.8)$ & 14.2 & $0.86 \mathrm{~d}(6.0)$ & 14 & $0.87 \mathrm{~d}(14.4)$ & 14.7 \\
\hline $17 \alpha$ & $4.39 \mathrm{~d}(12.0)$ & 63.6 & $4.81 \mathrm{~d}(12.0)$ & 64 & $4.58 \mathrm{~d}(11.4)$ & 63.4 & $4.67(\mathrm{~d}, J=11.4 \mathrm{~Hz})$ & 64.5 \\
\hline $17 \beta$ & $4.31 \mathrm{~d}(12.0)$ & & $4.46 \mathrm{~d}(12.0)$ & & $4.91 \mathrm{~d}(10.8)$ & & 4.46 brd (11.4) & \\
\hline 18 & $1.04 \mathrm{~s}$ & 29.5 & $1.05 \mathrm{~s}$ & 29.5 & $1.06 \mathrm{~s}$ & 29.5 & $1.05 \mathrm{~s}$ & 29.5 \\
\hline 19 & $0.90 \mathrm{~s}$ & 14.9 & $0.94 \mathrm{~s}$ & 14.9 & $0.95 \mathrm{~s}$ & 15 & $0.93 \mathrm{~s}$ & 14.9 \\
\hline 20 & $1.68 \mathrm{~s}$ & 24.6 & $1.73 \mathrm{~s}$ & 24.6 & $1.66 \mathrm{~s}$ & 25 & $1.71 \mathrm{~s}$ & 25.8 \\
\hline
\end{tabular}

${ }^{1} \mathrm{H}-\mathrm{NMR}$ of other signals ( $\delta$ ), for 1: O-Prop: $2.31(\mathrm{q}, J=7.0 \mathrm{~Hz}), 1.08(\mathrm{t}, J=7.0 \mathrm{~Hz}) ; \mathrm{O}-3 \mathrm{MeBu}, 1.97 \mathrm{~m}, 2.32 \mathrm{~m}, 0.90(\mathrm{~d}$, $J=7.8 \mathrm{~Hz}), 0.92(\mathrm{~d}, J=7.8 \mathrm{~Hz})$; OAc-7, 2.08 (s); OAc-13, 2.09 (s); OAc-17, 2.06 (s). For 2: O-Prop: 2.30 (q, $J=8.4 \mathrm{~Hz})$, $1.08(\mathrm{t}, J=8.4 \mathrm{~Hz}) ; \mathrm{O}-i \mathrm{Bu}, 2.39 \mathrm{~m}, 1.07(\mathrm{~d}, J=7.0 \mathrm{~Hz}), 1.09(\mathrm{~d}, J=7.0 \mathrm{~Hz}) ; \mathrm{OBz}, 7.91\left(\mathrm{AA}^{\prime}\right), 7.58$ (C), 7.47; OAc-7, 2.14 (s); OAc-13, 2.15 (s). For 3: O-Prop: 1.08 (t, $J=7 \mathrm{~Hz}), 2.45$ (q, $J=7 \mathrm{~Hz})$; OBz, 7.70 (brd, $J=7.2 \mathrm{~Hz}$ ), 7.52 (brdd, $J=7.2 \mathrm{~Hz}), 7.33 \mathrm{~m}, 7.11(\mathrm{~m}), 7.00(\mathrm{brt}, J=7.2)$; OAc-7, $2.12(\mathrm{~s})$; OAc-13, $2.17(\mathrm{~s})$. For 4: O-Prop: $1.08(\mathrm{t}, J=7.8 \mathrm{~Hz}), 2.25$ $(\mathrm{q}, J=9.0 \mathrm{~Hz}) ; \mathrm{O}-\mathrm{MeBu}, 2.14 \mathrm{~m}, 1.29 \mathrm{~m}, 1.06(\mathrm{~d}, J=7.8 \mathrm{~Hz}), 1.07(\mathrm{t}, J=7.8 \mathrm{~Hz}) ; \mathrm{O}-\mathrm{Nic}, 7.43(\mathrm{dd}, J=4.8,7.8 \mathrm{~Hz}), 8.18$ $(\mathrm{t}, J=7.8 \mathrm{~Hz}), 8.80(\mathrm{br} \mathrm{d}, J=7.8 \mathrm{~Hz}), 9.14 \mathrm{br} \mathrm{s}$; OAc-7, $2.10(\mathrm{~s})$; OAc-13, $2.05(\mathrm{~s}) .{ }^{13} \mathrm{C}-\mathrm{NMR}$ other signals $(\delta)$, for 1 : O-Prop: 8.9, 27.8; O-3MeBu, 21.4, 21.4, 26.5, 42.8; OAc-7, 170.0; OAc-13, 170.7; OAc-17, 170.4; C=O (prop, 174.2); C=O (3-MeBu, 174.3). For 2: O-Prop: 8.9, 27.7; O-iBu, 34.9, 18.6, 19.0; OBz, 128.9, 129.4, 133.6, 128.9, 129.4, 130.1; OAc-7, 170.0; OAc-13, 170.0; $\mathrm{C}=\mathrm{O}$ (prop, 170.7); $\mathrm{C}=\mathrm{O}$ (iBu, 174.1). For 3: O-Prop: 8.8,27.6; OBz-17, 132.9, 129.2, 127.9, 132.7, $127.9,129.2,129.4 ;$ OBz-5, $129.4,129.2,127.9,129.6,127.9,129.2 ;$ OAc-7, 170.2; OAc-13, 170.2; $\mathrm{C}=\mathrm{O}$ (prop, 170.8); $\mathrm{C}=\mathrm{O}$ (OBz-5, 165.3); $\mathrm{C}=\mathrm{O}$ (OBz-17, 173.6). For 5: O-Prop: 8.9, 27.8; O-MeBu, 11.6, 40.8, 14.9, 26.0; O-Nic, 153.9, 150.6, 136.9, 125.8, 123.7; OAc-7, 170.0; OAc-13, 170.7.

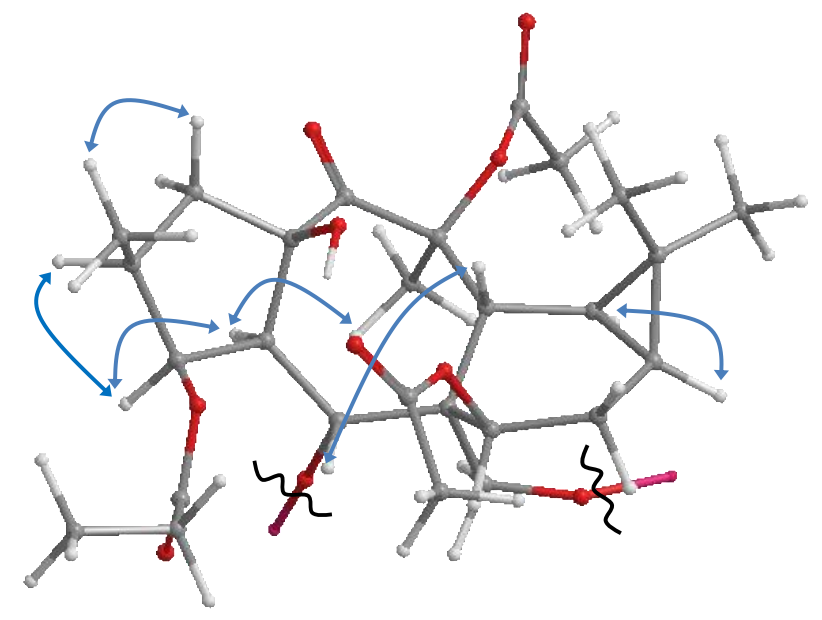

Figure 3. Observed NOESY correlations for 1-4.

Compound 2 was obtained as colorless oil with positive optical rotation $\left([\alpha]_{\mathrm{D}}^{25}+27.0\right.$ in $\left.\mathrm{MeOH}\right)$. HRFABMS analysis showed a molecular ion peak at $m / z 721.3206[\mathrm{M}+\mathrm{Na}]^{+}$corresponding to a molecular formula of $\mathrm{C}_{38} \mathrm{H}_{50} \mathrm{O}_{12} \mathrm{Na}$ (calcd. 721.3200). The IR spectrum displayed absorption 
bands for $\mathrm{OH}\left(3532 \mathrm{~cm}^{-1}\right)$ and ester carbonyl $\left(1741 \mathrm{~cm}^{-1}\right)$ groups, as well as characteristic aromatic ring absorptions (1450 and $716 \mathrm{~cm}^{-1}$ ). 1D- and 2D-NMR spectra (Table 1, Figures 2 and 3) were similar to those of previously published $7[25,26]$ albeit signals for the acetate group at C-17 are replaced by a benyzoly moiety in 2. NOESY correlations were observed to be the same for both 2 and 6. Therefore 2 was assigned as premyrsinol-3-propanoate-5-isobutyrate-7,13-diacetate-17-benzoate (euphosantianane B).

Compound 3 was obtained as colorless oil with positive optical rotation $\left([\alpha]_{\mathrm{D}}^{25}+64.0\right.$ in $\left.\mathrm{MeOH}\right)$. HRFABMS analysis showed a molecular ion peak at $m / z 755.3050[\mathrm{M}+\mathrm{Na}]^{+}$corresponding to a molecular formula of $\mathrm{C}_{38} \mathrm{H}_{50} \mathrm{O}_{12} \mathrm{Na}$ (calcd. 755.3043). The IR spectrum displayed absorption bands for $\mathrm{OH}\left(3532 \mathrm{~cm}^{-1}\right)$ and ester carbonyl $\left(1741 \mathrm{~cm}^{-1}\right)$ groups, as well as characteristic aromatic ring absorptions (1450 and $716 \mathrm{~cm}^{-1}$ ). 1D- and 2D-NMR spectra (Table 1, Figures 2 and 3) were similar to those of compound 2 except for an isoproponate group at C-5 in $\mathbf{2}$ being replaced by a second benyzoly moiety in 3 . The same NOESY correlations were detected in both 2 and 3 . Therefore, the structure was assigned as premyrsinol-3-propanoate-5-benzoate-17-benzoyl (euphosantianane C).

Compound 4 was obtained as colorless oil with positive optical rotation $\left([\alpha]_{\mathrm{D}}^{25}+30.4\right.$ in $\left.\mathrm{MeOH}\right)$. HRFABMS analysis showed a molecular ion peak at $m / z 736.3312[\mathrm{M}+\mathrm{Na}]^{+}$corresponding to a molecular formula of $\mathrm{C}_{38} \mathrm{H}_{50} \mathrm{O}_{12} \mathrm{Na}$ (calcd. 736.3309). The IR spectrum displayed absorption bands for $\mathrm{OH}\left(3532 \mathrm{~cm}^{-1}\right)$ and ester carbonyl $\left(1741 \mathrm{~cm}^{-1}\right)$ groups, as well as characteristic aromatic ring absorptions (1450 and $716 \mathrm{~cm}^{-1}$ ). 1D- and 2D-NMR spectra (Table 1, Figures 2 and 3) were similar to those of 5 except that the 2-methyl butyl substitution at C-17 in 5 was replaced by a nicotedial moiety in 4 . NOESY correlations were observed to be the same in both 4 and 5 [16]. Therefore, the structure was assigned as premyrsinol-3-propanoate-5( $\alpha$-2-methyl) butyrate-7,13-diacetate-17-nicotinate (euphosantianane D).

Nine known compounds have been isolated for the first time from $E$. sanctae-catharinae including five diterpenes: $7 \beta, 13 \beta, 17-O$-triacetyl-5 $\alpha-O$-(2-methylbutyryl)-3 $\beta$-O-propanoyl14-oxopremyrsinol (5) [16], premyrsinol-3-propanoate-5-isobutyrate-7,13,17-triacetate (6) [26], premyrsinol-3-propanoate-5isobutyrate-7,13-triacetate-17- nicotinate (7) [26], 4,20-Dideoxy(4 $\alpha)$ phorbol-12-benzoate-13-isobutyrate (8) [29], 4,12,20-trideoxyphorbol-13-(2,3-dimethyl) butyrate (9) [30]; and four flavonoid gylcosides: quercetin-3-O- $\alpha$-rhamnopyranoside (10) [31], kaempferol-3-O-rhamnoside (11) [32], myricetin-3-O-rhamnoside (12) [33], quercetin-3-O-galactopyranoside (13) [34].

The potent activity of 9 rather than it epimer encourage motivated a greater examination of the absolute configurations of $\mathbf{8}$ and $\mathbf{9}$ utilizing TDDFT-ECD calculations. Conformational search was first carried out using MMFF94S force field (time-dependent density functional) within a $10 \mathrm{kcal} / \mathrm{mol}$ energy window with the use of Omega2 software, OpenEye Scientific Software, Santa Fe, NM, USA. Molecular dynamics simulation of $10 \mathrm{~ns}$ was then performed for each conformer in methanol.

Uncorrelated snapshots were collected every 10 ps over $10 \mathrm{~ns}$ MD simulation and subjected to a geometrical optimization in methanol at the B3LYP /6-31G* level of theory, followed by frequency calculations. TDDFT calculations were then performed for each set of conformers at the same level of theory. The Boltzmann-weighted ECD (Equivalent Circulating Density) curves were generated and compared to the experimental spectra (Figure 4). The calculated ECD curves of compounds 8 and $\mathbf{9}$ gave a good agreement with the experimental data (Figure 4i,ii, respectively). A negative Cotton effect at $287 \mathrm{~nm}$ for the lactone ring $\pi \rightarrow \pi^{*}$ transitions and a positive Cotton effect of $315 \mathrm{~nm}$ for the lactone $\mathrm{n} \rightarrow \pi^{*}$ transitions was observed for $\mathbf{8}$, while $\mathbf{9}$ gave opposite Cotton effects (Figure 4). The TDDFT-ECD calculations and spectral data supported the conclusion that the absolute configuration at C-10 for 8 and 9 are $S$ and $R$, respectively. 


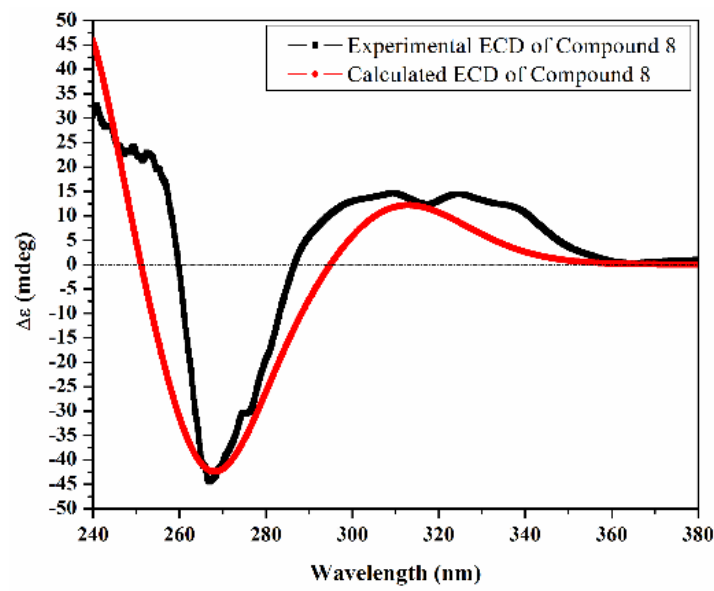

(i)

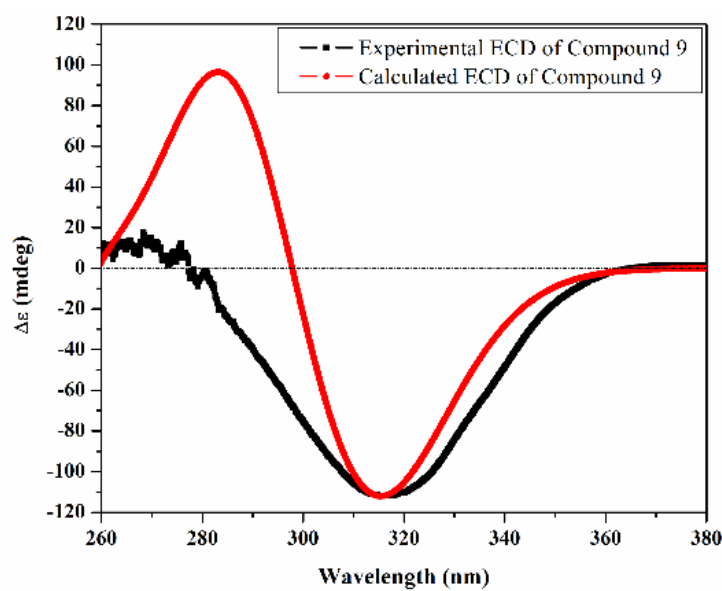

(ii)

Figure 4. Experimental and theoretical ECD spectra for compounds 8 (i) and 9 (ii).

Compounds 1-13 were tested for cytotoxic activity against human cancer cell lines of colon (Caco-2) and lung (A549) using doxorubicin $\mathrm{HCl}$ as positive control (Figure 5A,B and Table 2). Compound 9 showed the highest cytotoxic activity against lung cancer cells with an IC50 value of $3.3 \mu \mathrm{M}$ (Figure 6), while an epimer of 8 exhibited cytotoxic activity against colon cancer cells with an $\mathrm{IC}_{50}$ of $26.1 \mu \mathrm{M}$.

Table 2. $\mathrm{IC}_{50}$ values for $\mathbf{1} \mathbf{- 1 3}$ against proliferation of human Caco-2 and A549 tumor cell lines.

\begin{tabular}{ccc}
\hline Compound & IC $_{\mathbf{5 0}}$ on Caco-2 $(\boldsymbol{\mu M})^{\mathbf{a}}$ & IC $_{\mathbf{5 0}}$ on $\mathbf{A 5 4 9}(\boldsymbol{\mu M})^{\mathbf{a}}$ \\
\hline $\mathbf{1}$ & $75.8(0.950)$ & $>100$ \\
$\mathbf{2}$ & $40.5(0.989)$ & $48.5(0.927)$ \\
$\mathbf{3}$ & $31.0(0.999)$ & $21.5(0.924)$ \\
$\mathbf{4}$ & $33.2(0.993)$ & $32.8(0.988)$ \\
$\mathbf{5}$ & $43.5(0.999)$ & $50.1(0.9960)$ \\
$\mathbf{6}$ & $33.3(0.984)$ & $33.1(0.983)$ \\
$\mathbf{7}$ & $40.3(0.979)$ & $60.3(0.937)$ \\
$\mathbf{8}$ & $26.1(0.979)$ & $31.3(0.971)$ \\
$\mathbf{9}$ & $29.4(0.972)$ & $3.3(0.996)$ \\
$\mathbf{1 0}$ & $43.9(0.975)$ & $>100$ \\
$\mathbf{1 1}$ & $50.2(0.993)$ & $>100$ \\
$\mathbf{1 2}$ & $44.7(0.961)$ & $>100$ \\
$\mathbf{1 3}$ & $79.4(0.843)$ & $0.4(0.987)$ \\
Doxorubicin HCl & $0.7(0.999)$ & $>100$ \\
\hline
\end{tabular}

a Goodness of fit values $\left(\mathrm{R}^{2}\right)$ given in parentheses based on non-linear regression using GraphPad prism $\mathrm{V} 6.0$ software (GraphPad Software Inc., San Diego, CA, USA). 

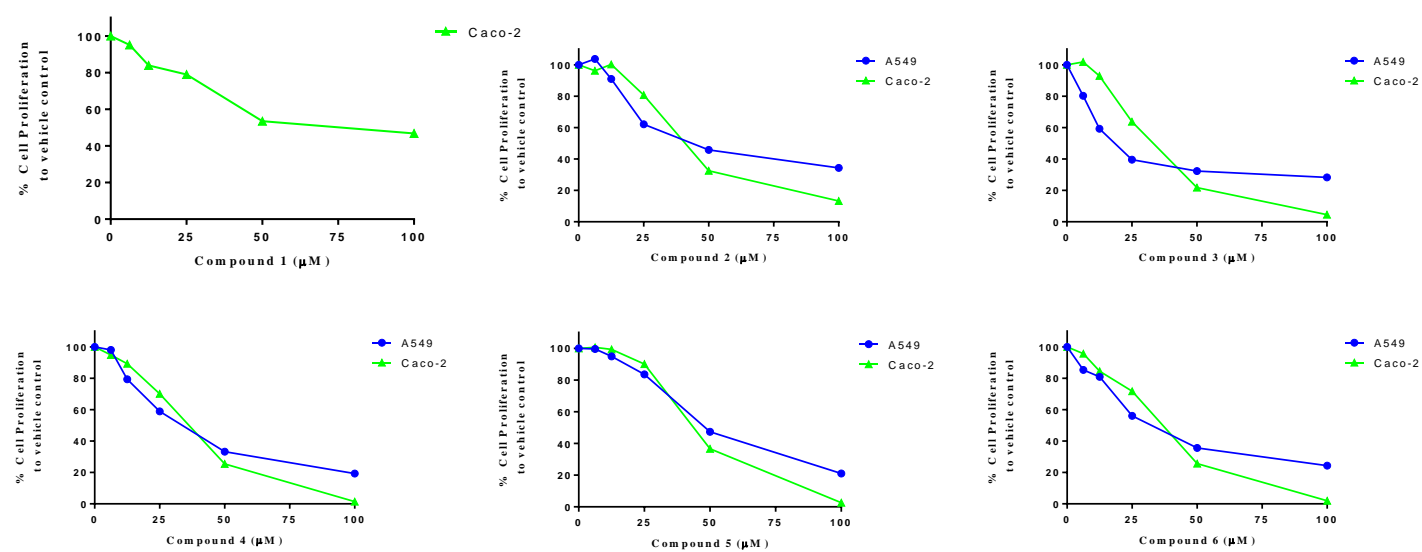

(A)
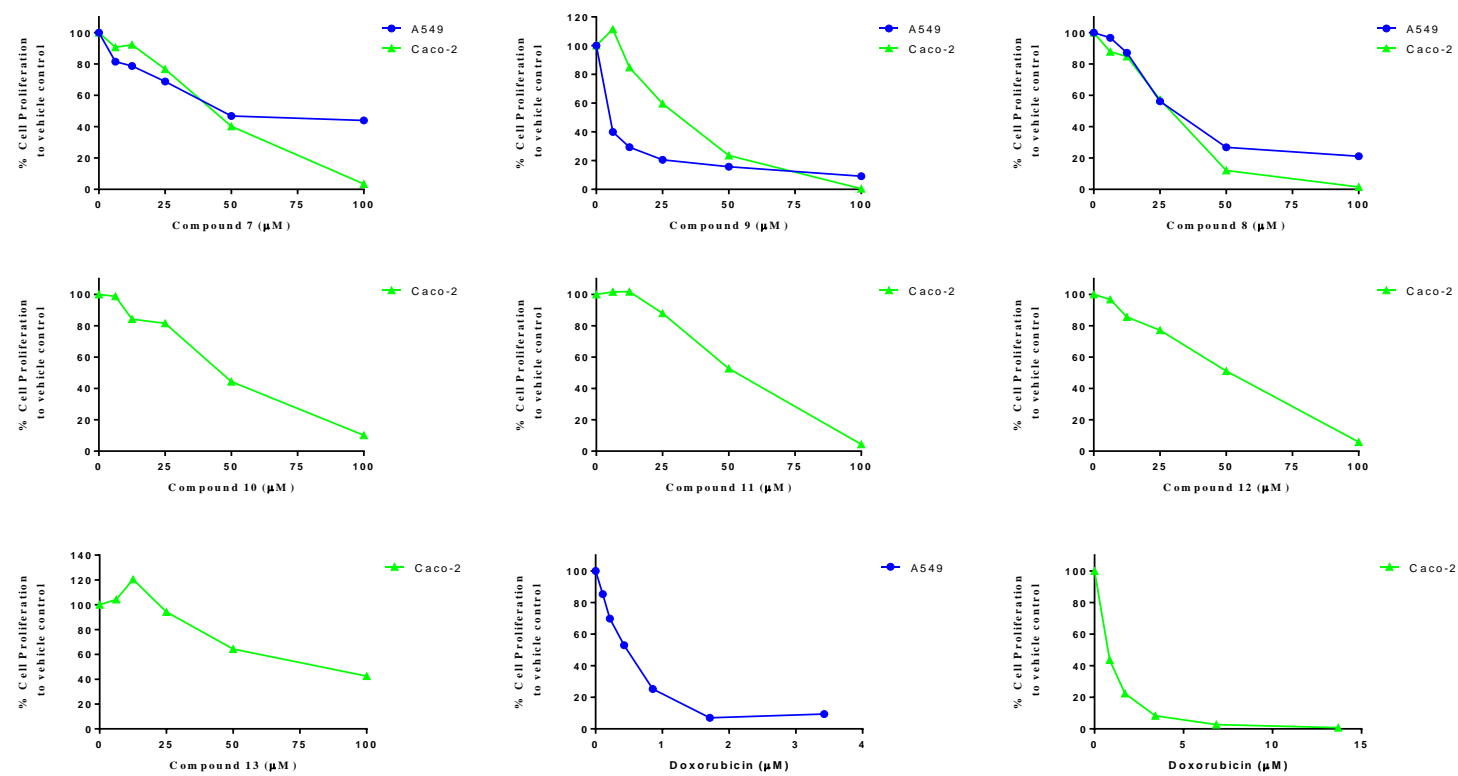

(B)

Figure 5. Concentration-response curve fits of the effect of isolated compounds 1-6 (A) and 7-13 (B) on the cell proliferation of Caco-2 (green triangles) or A549 (blue spheres). Cell proliferation was determined as \% of vehicle control (MTT reduction assay) as detailed in the Experimental section.

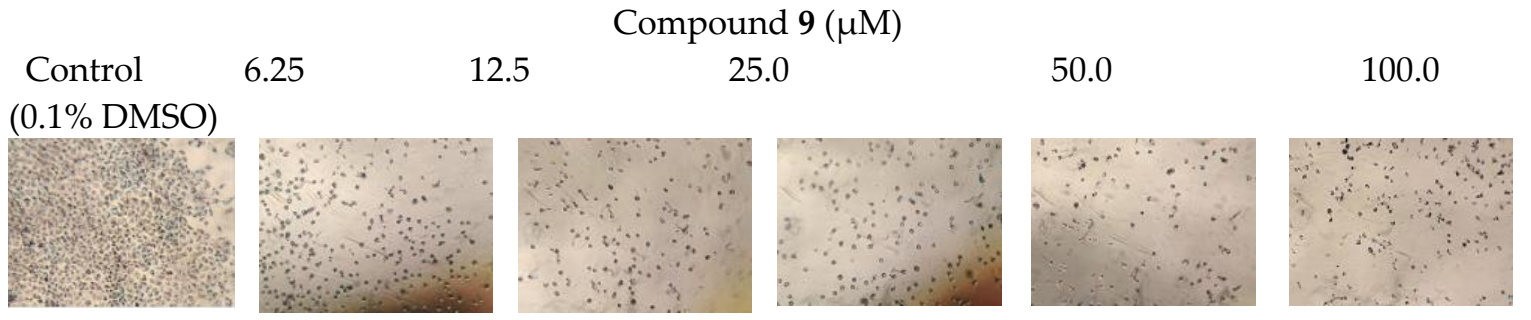

Figure 6. Photomicrographic images of A549 cells depict increasing morphological toxicity include cell monolayer disruption and cell shrinkage with $48 \mathrm{~h}$ exposure to 9 at increasing concentrations. Magnification $=150 \times$. 


\section{Experimental Section}

\subsection{General Experimental Procedures}

Specific rotation was measured with Perkin-Elmer-341 MC digital polarimeter (Wellesley, MA, USA) and IR spectra were collected on a JASCO FT/IR-6300 spectrometer (Easton, MD, USA). ${ }^{1} \mathrm{H}-$ and ${ }^{13} \mathrm{C}-\mathrm{NMR}$ spectra were recorded in $\mathrm{CDCl}_{3}$ on a JEOL ECA- 600 spectrometer $\left(600 \mathrm{MHz}\right.$ for ${ }^{1} \mathrm{H}$ and $150 \mathrm{MHz}$ for ${ }^{13} \mathrm{C}$ ) (JEOL Ltd., Tokyo, Japan). All chemical shifts $(\delta)$ are given in ppm units with reference to TMS as an internal standard and coupling constants $(J)$ are reported in Hz. FAB-MS experiments were performed using a Thermo ISQ Single Quadrupole system and HR-FAB-MS experiments were performed on Fourier transform ion cyclotron mass spectrometer (Thermo Scientific, San Jose, CA, USA). High performance liquid chromatography (HPLC) was performed with an Agilent pump equipped with an Agilent-1200 with refractive index (RI) detector (Santa Clara, CA, USA) and a semi-preparative reversed-phase column (Econosphere ${ }^{\mathrm{TM}}$, RP-C18, $5 \mu \mathrm{m}, 250 \times 4.6 \mathrm{~mm}$, Alltech, Deerfield, IL, USA). Silica gel 60 (230-400 mesh, Merck, Darmstadt, Germany) was used for column chromatography; reversed-phase silica gel for column chromatography, Chromatorex ODS DM1020T (Fuji Silysia Chemical, Ltd., 100-200 mesh. Pre-coated silica gel plates (Kieselgel 60 F254, 0.25 mm, Merck, Darmstadt, Germany) were used for TLC analyses. Spots were visualized by heating after spraying with $10 \% \mathrm{H}_{2} \mathrm{SO}_{4}$.

\subsection{Plant Material}

Euphorbia sanctae-catharinae plants were collected in May 2013 from Wadi Jibaal in St Katherine Protectorate, south Sinai, Egypt in the flowering stage. A voucher specimen (\#212) has been deposited in the herbarium of the National Research Centre. The collection was taking place under the permission of St Katherine Protectorate for scientific purposes. The plant was kindly authenticated by Dr. Mona Marzouk, Associate Professor of Taxonomy, National Research Center, Cairo, Egypt.

\subsection{Extraction and Isolation}

Aerial parts $\left(2.0 \mathrm{~kg}\right.$ ) were powdered and extracted with $\mathrm{CH}_{2} \mathrm{Cl}_{2}: \mathrm{MeOH}(1: 1)$ at room temperature. The extract was concentrated in vacuo to obtain a gummy residue $(110 \mathrm{~g})$. The concentrated crude extract $(110 \mathrm{~g})$ was fractionated on silica gel flash CC $(5 \times 60 \mathrm{~cm})$ and eluted with gradient solvents of increasing polarity starting with $(100 \%) n$-hexane followed by a gradient of $n$-hexane/ethyl acetate up to $100 \%$ ethyl acetate. Seventeen fractions were collected and pooled together according to the TLC profile (using solvent systems: S1: n-hexane:EtOAc (4:1 v/v), S2: methylene chloride:methanol (7:0.5 $v / v)$, S3: n-hexane:EtOAc $(1: 1 v / v))$. Vanillin-sulphuric acid spray reagent was used as spray reagents for spots dete ction on the chromatograms. The chromatograms were visualized in visible and under UV light (at $254 \mathrm{~nm}$ and $365 \mathrm{~nm}$ ). Similar fractions were combined according to their chromatographic patterns to yield nine collected fractions. These fractions were then subjected for chemical investigation. The nine different subfractions that obtained were A $(10 \mathrm{gm}), \mathrm{B}(8 \mathrm{gm}), \mathrm{C}(8.5 \mathrm{gm}), \mathrm{D}(6 \mathrm{gm}), \mathrm{E}(10 \mathrm{gm})$, F (12 gm), G (11 gm), H (9 gm), I (20 gm). From TLC profiles, fractions that appeared to contain mainly fatty acids and low levels of terpenes and flavonoids were not advanced for additional HPLC purification. Fraction D (6 gm) as subjected to further fractionation on ODS column $(3 \times 60 \mathrm{~cm})$ using $85 \% \mathrm{MeOH}: 15 \% \mathrm{H}_{2} \mathrm{O}$ and finally wash with $100 \% \mathrm{MeOH}$. The obtained fraction was subjected to isolation and purification by a reversed phase HPLC $(20 \times 250 \mathrm{~cm})$ using $\mathrm{MeOH}: \mathrm{H}_{2} \mathrm{O}(85 \%: 15 \%$, $2.5 \mathrm{~L})$ to afford nine compounds $(\mathbf{1}, 20 \mathrm{mg}),(2,8.5 \mathrm{mg}),(3,7.0 \mathrm{mg}),(4,6.5 \mathrm{mg}),(5,14 \mathrm{mg}),(6,11 \mathrm{mg})$, $(7,8 \mathrm{mg}),(8,9 \mathrm{mg})$ and $(9,6 \mathrm{mg})$. Fraction $\mathrm{F}(12 \mathrm{gm})$ was also subjected to further fractionation on ODS column $(3 \times 60 \mathrm{~cm})$ using $\left(85 \% \mathrm{MeOH}: 15 \% \mathrm{H}_{2} \mathrm{O}\right)$ and finally washed with $100 \% \mathrm{MeOH}$. The obtained fraction was further purified by a reversed phase HPLC using MeOH: $\mathrm{H}_{2} \mathrm{O}(1: 1,2.5 \mathrm{~L})$ to afford one compound (10,6.5 $\mathrm{mg})$. Fraction $\mathrm{G}(11 \mathrm{gm})$ was also subjected for isolation and purification by a reversed phase HPLC using $\mathrm{MeOH}: \mathrm{H}_{2} \mathrm{O}(1: 1,2.5 \mathrm{~L})$ to afford one compound (11, $\left.7 \mathrm{mg}\right)$. Fraction 
$\mathrm{H}(9 \mathrm{mg})$ was subjected for isolation and purification by a reversed phase $\mathrm{HPLC}$ using $\mathrm{MeOH} / \mathrm{H}_{2} \mathrm{O}$ $(50 \% / 50 \%, 2.5 \mathrm{~L})$ to afford two compounds $(\mathbf{1 2}, 8.5 \mathrm{mg})$ and $(\mathbf{1 3}, 6 \mathrm{mg})$.

Premyrsinol-3-propanoate-5( $\alpha$-3methyl)butyrate-7,13,17-triacetate (euphosantianane A, 1): colorless oil; $[\alpha]_{\mathrm{D}}^{25}+20.0(\mathrm{c} 0.01, \mathrm{MeOH})$; FT-IR (KBr) v $\max : 3532,1741,1450$ and $716 \mathrm{~cm}^{-1} ;{ }^{1} \mathrm{H}-$ and ${ }^{13} \mathrm{C}-\mathrm{NMR}$ data, see Table S1; HRFABMS $\mathrm{m} / z$ 673.3203(M + Na); (calcd. for $\mathrm{C}_{20} \mathrm{H}_{30} \mathrm{O}_{2} \mathrm{Na}, 673.3200$ ).

Premyrsinol-3-propanoate-5-isobutyrate-7,13diacetate-17-benzoate (euphosantianane B, 2): white powder; $[\alpha]_{\mathrm{D}}^{25}+27.0($ c $0.01, \mathrm{MeOH})$ ); FT-IR (KBr) $\mathrm{v}_{\max }$ : 3532, 1741, 1450 and $716 \mathrm{~cm}^{-1} ;{ }^{1} \mathrm{H}-$ and ${ }^{13} \mathrm{C}$-NMR data, see Table S1; HRFABMS $m / z 721.3206(\mathrm{M}+\mathrm{Na}) ;\left(\right.$ calcd. for $\left.\mathrm{C}_{38} \mathrm{H}_{50} \mathrm{O}_{12} \mathrm{Na}, 721.3200\right)$.

Premyrsinol-3-propanoate-5-benzoate-17-benzoyl (euphosantianane $\mathrm{C}, 3$ ): white powder; $[\alpha]_{\mathrm{D}}^{25}$ + 64.0 (c 0.01, MeOH); FT-IR (KBr) $\mathrm{v}_{\max }: 3532,1741,1450$ and $716 \mathrm{~cm}^{-1} ;{ }^{1} \mathrm{H}$ - and ${ }^{13} \mathrm{C}-\mathrm{NMR}$ data, see Table S1; HRFABMS $m / z 755.3050$ (M + Na); (calcd. for $\mathrm{C}_{41} \mathrm{H}_{48} \mathrm{O}_{12} \mathrm{Na}$, 755.3043).

Premyrsinol-3-propanoate-5( $\alpha$-2methyl)butyrate-7,13-diacetate-17-nicotinate (euphosantianane $\mathrm{D}, 4)$ : white powder; $[\alpha]_{\mathrm{D}}^{25}+30.4(\mathrm{c} 0.01, \mathrm{MeOH})$; FT-IR $(\mathrm{KBr}) \mathrm{v}_{\max }: 3532,1741,1450$ and $716 \mathrm{~cm}^{-1}$; ${ }^{1} \mathrm{H}$ - and ${ }^{13} \mathrm{C}-\mathrm{NMR}$ data, see Table S1; HRFABMS $m / z 736.3312(\mathrm{M}+\mathrm{Na})$; (calcd. for $\mathrm{C}_{38} \mathrm{H}_{51} \mathrm{O}_{12} \mathrm{NNa}$, 736.3309).

\subsection{Biological Activity}

\subsubsection{Cell Culture}

All materials and reagents for the cell cultures were purchased from Lonza (Verviers, Belgium). Human colon cancer cell line Caco-2 and human lung cancer cell line A549 were maintained as monolayer culture in Dulbecco's modified Eagle's medium (DMEM) supplemented with $10 \%$ FBS, $4 \mathrm{mM}$ glutamine, $100 \mathrm{U} / \mathrm{mL}$ penicillin, and $100 \mu \mathrm{g} / \mathrm{mL}$ streptomycin sulfate. Monolayers were passaged at $70-90 \%$ confluence using trypsin-EDTA solution. All cell incubations were maintained at humidified $\mathrm{CO}_{2}$ incubator with $5 \% \mathrm{CO}_{2}$ at $37^{\circ} \mathrm{C}$.

\subsubsection{Cell Proliferation Assay}

Anti-proliferative studies were performed using a modified MTT (3-[4,5-dimethylthiazole-2-yl]-2, 5-diphenyltetrazolium bromide) assay based on a previously published method [35,36]. Appropriate cell densities of exponentially growing A549 and Caco-2 cells (5000 cells/well) were seeded onto 96-well plates. After a $24 \mathrm{~h}$ incubation period with $5 \% \mathrm{CO}_{2}$ at $37{ }^{\circ} \mathrm{C}$, stock test compounds (1-13) dissolved in dimethyl sulfoxide (DMSO) were added at concentrations of 100, 50, 25, 12.5, and $6.25 \mu \mathrm{M}$ in culture medium (final DMSO concentration in medium $=0.1 \%$, by volume). After $48 \mathrm{~h}$ of incubation, MTT solution in PBS $(5 \mathrm{mg} / \mathrm{mL})$ was added to each well, after which the incubation was resumed for a further $90 \mathrm{~min}[37,38]$. The formation of intracellular formazan crystals (mitochondrial reduction product of MTT) was confirmed by a phase contrast microscopic examination. Photomicrographs were taken using an inverted microscope (Ziess, Germany) with attached eye-piece digital camera (Total magnification $=150 \times$ ). At the end of the incubation period, the medium was removed and $100 \mu \mathrm{L}$ of DMSO was added to each well to dissolve formed formazan crystals with shaking for $10 \mathrm{~min}$ (200 rpm). Dissolved crystals were quantified by reading the absorbance at $492 \mathrm{~nm}(\mathrm{OD})$ on a microplate reader (Sunrise $^{\mathrm{TM}}$ microplate reader, Tecan Austria GmbH, Grödig, Austria) and were used as a measure of cell proliferation.

\subsubsection{Anti-Proliferation Quantitative Analysis}

Cell proliferation was determined by comparing the average OD values of the control wells with those of the samples (quadrate to octuplet treatments) both represented as \% proliferation [control proliferation $(0.1 \% \mathrm{DMSO})=100 \%$. The $\mathrm{IC}_{50}$ values (concentration of sample causing $50 \%$ loss of cell proliferation of the vehicle control) were calculated using the concentration-response curve fit to the non-linear regression model using GraphPad Prism ${ }^{\circledR}$ v6.0 software (GraphPad Software Inc., San Diego, CA, USA). 


\subsection{Computational Calculations}

Conformational ensembles for 8 and $\mathbf{9}$ were generated with MMFF94S force field and an energy window of $10 \mathrm{kcal} / \mathrm{mol}$ using Omega 2 software [39,40]. To avoid missing any possible conformers, all generated conformers were subjected to molecular dynamics (MD) simulation for $10 \mathrm{~ns}$ in methanol with AMBER14 software (University of California, San Francisco, CA, USA) [41]. Uncorrelated conformations were then collected every $10 \mathrm{ps}$ over the $10 \mathrm{~ns}$ MD simulation time and minimized using the truncated Newton linear conjugate gradient method with LBFGS preconditioning implemented in AMBER14 software [41]. All unique conformations, in terms of energy, were then geometrically optimized at the B3LYP /6-31G* level of theory using Gaussian09 (Gaussian, Inc., Wallingford CT, USA) [42]. A vibrational frequency calculation was performed to confirm the minimum energy state of the optimized conformers as well as to calculate the corresponding free energies. TDDFT calculations were carried out at the B3LYP /6-31G* level of theory and the first 50 excitation states were calculated. To consider the solvent effect in optimization and TDDFT calculations, a polarizable continuum model (PCM) using methanol as a solvent was incorporated. ECD spectra were then generated using the SpecDis 1.71 (Berlin, Germany) [43,44] by applying Gaussian band shapes with sigma $=0.25 \mathrm{ev}$. The theoretical ECD spectrum was generated by averaging the ECD spectra of each conformer using Boltzmann statistics. Wavelength shift and intensity scaling were applied in the computational/experimental comparison.

Supplementary Materials: The supplementary materials are available online at http:/ /www.mdpi.com/14203049/23/9/2221/s1.

Author Contributions: M.-E.F.H. and E.H.R. contributed to the extraction, isolation, purification, identification, and manuscript preparation. A.R.H. contributed to the cytotoxicity experiments, analysis, and manuscript preparation. M.A.A.I. contributed to the computational studies, analysis, and manuscript preparations. S.N., H.M. contribute to analyses, and manuscript preparations. Z.T., N.S.A.-A., F.M.H., E.G.H., P.W.P. and T.E. contributed to the structure elucidation, guiding experiments, and manuscript preparations. M.-E.F.H. was the project leader, organizing and guiding the experiments, structure elucidation, and manuscript writing.

Funding: This research was funded by the Welch Foundation (D-1478), the Alexander von Humboldt Foundation (Georg Foster Research Fellowship for Experienced Researcher, for M.-E.F.H.), Germany.

Acknowledgments: This work was financially supported by National Research Centre, Egypt, the Welch Foundation (D-1478), and the Alexander von Humboldt Foundation (Georg Foster Research Fellowship for Experienced Researcher, for M.-E.F.H.), Germany. The computational work was completed in part with resources supported by the Science and Technology Development Fund, STDF, Egypt, Grants No. 5480 \& 7972.

Conflicts of Interest: The authors declare that there is no conflict of interest.

\section{References}

1. Barla, A.; Bİrman, H.; Kültür, Ş.; Öksüz, S. Secondary metabolites from Euphorbia helioscopia and their vasodepressor activity. Turk. J. Chem. 2006, 30, 325-332.

2. Batanouny, K.H.; Stichler, W.; Ziegler, H. Phytosynthetic pathways and ecological distribution of Euphorbia species in Egypt. Oecologia 1991, 87, 565-569. [CrossRef] [PubMed]

3. Yasukawa, K.; Akihisa, T.; Yoshida, Z.Y.; Takido, M. Inhibitory effect of euphol, a triterpene alcohol from the roots of Euphorbia kansui, on tumour promotion by 12-O-tetradecanoylphorbol-13-acetate in two-stage carcinogenesis in mouse skin. J. Pharm. Pharmacol. 2000, 52, 119-124. [CrossRef] [PubMed]

4. Delgado, I.F.; De-Carvalho, R.R.; De-Oliveira, A.C.; Kuriyama, S.N.; Oliveira-Filho, E.C.; Souza, C.A.; Paumgartten, F.J. Absence of tumor promoting activity of Euphorbia milii latex on the mouse back skin. Toxicol. Lett. 2003, 145, 175-180. [CrossRef]

5. King, A.R.; Dotsey, E.Y.; Lodola, A.; Jung, K.M.; Ghomian, A.; Qiu, Y. Discovery of potent and reversible monoacylglycerol lipase inhibitors. Chem. Biol. 2009, 16, 1045-1052. [CrossRef] [PubMed]

6. Gupta, P.J. Discovery of potent and reversible monoacylglycerol lipase inhibitors. Eur. Rev. Med. Pharmacol. Sci. 2011, 15, 199-203. [PubMed]

7. Pracheta, S.V.; Veena, S.; Ritu, P.; Sadhana, S. Preliminary Phytochemical Screening and in vitro Antioxidant Potential of Hydro-Ethanolic extract of Euphorbia neriifolia Linn. Int. J. Pharm. Tech. Res. 2011, 3, 124-132. 
8. Jie, C.; Xin, Y.; Ai-jun, D.; Da-you, C.; Jing, W.; Hai-tian, Z. Chemical composition and antioxidant activity of Euphorbia fischeriana essential oil from China. J. Med. Plants Res. 2011, 5, 4794-4798.

9. Tanaka, R.; Kasubuchi, K.; Kita, S.; Matsunaga, S. Obtusifoliol and related steroids from the whole herb of Euphorbia chamaesyce. Phytochemistry 1999, 51, 457-463. [CrossRef]

10. Ahmad, I.; Khan, A.U.; Chaudhary, B.A.; Janbaz, K.H.; Uzair, M.; Akhtar, M.; Gilani, A.H. Antifungal and antispasmodic activities of the extracts of Euphorbia granulata. J. Med. Plants Res. 2012, 6, 19-32.

11. Shu, X.; Yu, L.; Tang, Y.; Zhang, L.; Ding, A.; Luo, D. Bioassay-guided separation of the proinflamatory constituents from the roots of Euphorbia kansui. J. Nat. Med. 2010, 64, 98-103. [CrossRef] [PubMed]

12. Lan, W.; Peijian, Z.; Xiaofang, W. The Application of Antibacterial Components of Euphorbia Humifusa Willd on Silk Fabrics. Adv. Mater. Res. 2012, 441, 315-319.

13. Lirio, L.G.; Hermano, M.L.; Fontanilla, M.Q. Note antibacterial activity of medicinal plants from the Philippines. Pharm. Biol. 1998, 36, 357-359. [CrossRef]

14. Ibraheim, Z.Z.; Ahmed, A.S.; Abdel-Mageed, W.M. Chemical and biological studies of Euphorbia aphylla. J. Nat. Prod. 2013, 13, 35-45.

15. Esposito, M.; Nothias, L.-E.; Retailleau, P.; Costa, J.; Roussi, F.; Neyts, J.; Leyssen, P.; Touboul, D.; Litaudon, M.; Paolini, J. Isolation of Premyrsinane, Myrsinane, and Tigliane Diterpenoids from Euphorbia pithyusa Using a Chikungunya Virus Cell-Based Assay and Analogue Annotation by Molecular Networking. J. Nat. Prod. 2017, 80, 2051-2059. [CrossRef] [PubMed]

16. Kawashty, S.A.; Abdalla, M.F.; El-Hadidi, M.N.; Saleh, N.A.M. The chemosystematics of Egyptian Euphorbia species. Biochem. Syst. Ecol. 1990, 18, 487-490. [CrossRef]

17. Saleh, N.A. Flavonol glycosides of Euphorbia retusa and E. sanctae-catharinae. Phytochemistry 1985, 24, 371-372. [CrossRef]

18. Hegazy, M.E.F.; Abd El-Razek, M.H.; Nagashima, F.; Asakawa, Y.; Paré, P.W. Rare prenylated flavonoids from Tephrosia purpurea. Phytochemistry 2009, 70, 1474-1477. [CrossRef] [PubMed]

19. Hegazy, M.-E.F.; Matsuda, H.; Nakamura, S.; Yabe, M.; Matsumoto, T.; Yoshikawa, M. Sesquiterpenes from an Egyptian Herbal Medicine, Pulicaria undulate, with Inhibitory Effects on Nitric Oxide Production in RAW264.7 Macrophage Cells. Chem. Pharm. Bull. 2012, 60, 363-370. [CrossRef] [PubMed]

20. Elmasri, W.A.; Hegazy, M.E.F.; Aziz, M.; Koksal, E.; Amor, W.; Mechref, Y.; Hamood, A.N.; Cordes, D.B.; Paré, P.W. Biofilm blocking sesquiterpenes from Teucrium polium. Phytochemistry 2014, 103, 107-113. [CrossRef] [PubMed]

21. Hegazy, M.E.F.; Matsuda, H.; Nakamura, S.; Hussein, T.A.; Yoshikawa, M.; Paré, P.W. Chemical constituents and their antibacterial and antifungal activity from the Egyptian herbal medicine Chiliadenus montanus. Phytochemistry 2014, 103, 154-161. [CrossRef] [PubMed]

22. Elmasri, W.A.; Yang, T.; Tran, P.; Hegazy, M.E.F.; Hamood, A.N.; Mechref, Y.; Paré, P.W. Teucrium polium phenylethanol and iridoid glycoside characterization and flavonoid inhibition of biofilm-forming staphylococcus aureus. J. Nat. Prod. 2015, 78, 2-9. [CrossRef] [PubMed]

23. Elmasri, W.A.; Yang, T.; Hegazy, M.E.F.; Mechref, Y.; Paré, P.W. Iridoid glycoside permethylation enhances chromatographic separation and chemical ionization. Rapid Commun. Mass Spectrom. 2016, 30, $2033-2042$. [CrossRef] [PubMed]

24. Hamed, A.R.; Hegazy, M.E.F.; Higgins, M.; Mohamed, T.A.; Abdel-Azim, N.S.; Pare, P.W.; Dinkova-Kostova, A.T. Potency of extracts from selected Egyptian plants as inducers of the Nrf2-dependent chemopreventive enzyme NQO1. J. Nat. Med. 2016, 70, 683-688. [CrossRef] [PubMed]

25. Hegazy, M.E.F.; Ibrahim, A.Y.; Mohamed, T.A.; Shahat, A.A.; El Halawany, A.M.; Abdel-Azim, N.S.; Alsaid, M.S.; Paré, P.W. Sesquiterpene Lactones from Cynara cornigera: Acetyl Cholinesterase Inhibition and in Silico Ligand Docking. Planta Med. 2016, 82, 138-146. [PubMed]

26. Appendino, G.; Belloro, E.; Tron, G.C.; Jakupovic, J.; Ballero, M. Diterpenoids from Euphorbia pithyusa subsp. cupanii. J. Nat. Prod. 1999, 62, 1399-1404. [CrossRef] [PubMed]

27. Zhang, W.J.; Chen, D.F.; Hou, A.J. New myrsinol diterpenes from Euphorbia prolifera. Chin. J. Chem. 2004, 22, 103-108. [CrossRef]

28. Shokoohinia, Y.; Sajjadi, S.E.; Zolfaghari, B.; Chianese, G.; Appendino, G.; Taglialatela-Scafati, O. Diterpenoid (poly)esters and a ring A-seco-phorboid from the aerial parts of Euphorbia macroclada Boiss. Fitoterapia 2010, 8, 884-890. [CrossRef] [PubMed] 
29. Aichour, S.; Haba, H.; Benkhaled, M.; Harakat, D.; Lavaud, C. Terpenoids and other constituents from Euphorbia bupleuroides. Phytochem. Lett. 2014, 10, 198-203. [CrossRef]

30. Dagang, W.; Sorg, B.; Hecker, E. Oligo and macrocyclic diterpenes in thymelaeaceae and Euphorbiaceae occurring and utilized in Yunnan (Southwest China). 6. Tigliane type diterpene esters from latex of Euphorbia prolifera. Phytother. Res. 1994, 8, 95-99. [CrossRef]

31. Jung, M.J.; Kang, S.S.; Jung, H.A.; Kim, G.J.; Choi, J.S. Isolation of flavonoids and a cerebroside from the stem bark of Albizzia julibrissin. Arch. Pharm. Res. 2004, 27, 593-599. [CrossRef] [PubMed]

32. Diantini, A.; Subarnas, A.; Lestari, K.; Halimah, E.; Susilawati, Y.; Supriyatna, S.; Kobayashi, K. Kaempferol-3-O-rhamnoside isolated from the leaves of Schimawallichii Korth. inhibits MCF-7 breast cancer cell proliferation through activation of the caspase cascade pathway. Oncol. Lett. 2012, 3, 1069-1072. [CrossRef] [PubMed]

33. David, J.M.; Cruz, F.G.; Guedes, M.L.S.; Chávez, J.P. Flavonol glycosides from Davillaflexuosa. J. Braz. Chem. Soc. 1996, 7, 115-118. [CrossRef]

34. Agrawal, P.K. Carbon-13 NMR of Flavonoids; Elsevier Science: Amsterdam, The Netherlands, 1989; pp. $283-364$. ISBN 9781483290744.

35. Mosmann, T. Rapid colorimetric assay for cellular growth and survival: Application to proliferation and cytotoxicity assays. J. Immunol. Meth. 1983, 65, 55-63. [CrossRef]

36. Dutta, A.; Bandyopadhyay, S.; Mandal, C.; Chatterjee, M. Development of a modified MTT assay for screening antimonial resistant field isolates of Indian visceral leishmaniasis. Parasitol. Int. 2005, 54, 119-122. [CrossRef] [PubMed]

37. Hegazy, M.E.F.; El-Beih, A.A.; Hamed, A.R.; Abd El Aty, A.A.; Mohamed, N.S.; Paré, P.W. 3-Oxo- $\gamma$-costic acid fungal-transformation generates eudesmane sesquiterpenes with in vitro tumor-inhibitory activity. Bioorg. Med. Chem. Lett. 2017, 27, 3825-3828. [CrossRef] [PubMed]

38. Eldehna, W.M.; El-Naggar, D.H.; Hamed, A.R.; Ibrahim, H.S.; Ghabbour, H.A.; Abdel-Aziz, H.A. One-pot three-component synthesis of novel spirooxindoles with potential cytotoxic activity against triple-negative breast cancer MDA-MB-231 cells. J. Enzyme Inhib. Med. Chem. 2018, 33, 309-318. [CrossRef] [PubMed]

39. OMEGA 2.5.1.4; OpenEye Scientific Software: Santa Fe, NM, USA, 2017.

40. Hawkins, P.C.D.; Skillman, A.G.; Warren, G.L.; Ellingson, B.A.; Stahl, M.T. Conformer Generation with OMEGA: Algorithm and Validation Using High Quality Structures from the Protein Databank and Cambridge Structural Database. J. Chem. Inf. Model. 2010, 50, 572-584. [CrossRef] [PubMed]

41. Case, D.A.; Babin, V.; Berryman, J.T.; Betz, R.M.; Cai, Q.; Cerutti, D.S.; Cheatham, T.E.; Darden, T.A.; Duke, R.E.; Gohlke, H.; et al. AMBER 14; University of California: San Francisco, CA, USA, 2014.

42. Frisch, M.J.; Trucks, G.W.; Schlegel, H.B.; Scuseria, G.E.; Robb, M.A.; Cheeseman, J.R.; Scalmani, G.; Barone, V.; Mennucci, B.; Petersson, G.A.; et al. GAUSSIAN 09; Revision E.1; Gaussian, Inc.: Wallingford, CT, USA, 2009.

43. Bruhn, T.; Schaumlöffel, A.; Hemberger, Y.; Bringmann, G. SpecDis: Quantifying the comparison of calculated and experimental electronic circular dichroism spectra. Chirality 2013, 25, 243-249. [CrossRef] [PubMed]

44. Bruhn, T.; Schaumlöffel, A.; Hemberger, Y.; Pescitelli, G. SpecDis version 1.71; Berlin, Germany. 2017. Available online: https:/specdis-software.jimdo.com (accessed on 18 August 2018).

Sample Availability: Samples of the compounds 1-13 are not available from the authors.

(C) 2018 by the authors. Licensee MDPI, Basel, Switzerland. This article is an open access article distributed under the terms and conditions of the Creative Commons Attribution (CC BY) license (http:// creativecommons.org/licenses/by/4.0/). 